\title{
The Role of Antimicrobial Peptides in Preterm Birth
}

\author{
Ga-Hyun Son ${ }^{1,2, * \mathbb{D}}$, Jae-Jun Lee ${ }^{2,3}$, Youngmi Kim ${ }^{2}$ and Keun-Young Lee ${ }^{1}$ \\ 1 Division of Maternal-Fetal Medicine, Department of Obstetrics and Gynecology, \\ Hallym University College of Medicine, Kangnam Sacred Heart Hospital, Seoul 07441, Korea; \\ mfmlee@hallym.ac.kr \\ 2 Institute of New Frontier Research Team, College of Medicine, Hallym University, Chuncheon 24523, Korea; \\ iloveu59@hallym.or.kr (J.-J.L.); kym8389@hanmail.net (Y.K.) \\ 3 Departments of Anesthesiology and Pain Medicine, College of Medicine, Hallym University, \\ Chuncheon 24523, Korea \\ * Correspondence: gahyuns@hallym.or.kr; Tel.: +82-2-6960-1205
}

Citation: Son, G.-H.; Lee, J.-J.; Kim

Y.; Lee, K.-Y. The Role of

Antimicrobial Peptides in Preterm

Birth. Int. J. Mol. Sci. 2021, 22, 8905.

https: / / doi.org/10.3390/

ijms22168905

Academic Editor: Jerome F. Strauss III

Received: 8 July 2021

Accepted: 16 August 2021

Published: 18 August 2021

Publisher's Note: MDPI stays neutral with regard to jurisdictional claims in published maps and institutional affiliations.

Copyright: (C) 2021 by the authors. Licensee MDPI, Basel, Switzerland. This article is an open access article distributed under the terms and conditions of the Creative Commons Attribution (CC BY) license (https:/ / creativecommons.org/licenses/by/ $4.0 /)$.

\begin{abstract}
Antimicrobial peptides (AMPs) are short cationic amphipathic peptides with a wide range of antimicrobial properties and play an important role in the maintenance of immune homeostasis by modulating immune responses in the reproductive tract. As intra-amniotic infection and microbial dysbiosis emerge as common causes of preterm births (PTBs), a better understanding of the AMPs involved in the development of PTB is essential. The altered expression of AMPs has been reported in PTB-related clinical presentations, such as preterm labor, intra-amniotic infection/inflammation, premature rupture of membranes, and cervical insufficiency. Moreover, it was previously reported that dysregulation of AMPs may affect the pregnancy prognosis. This review aims to describe the expression of AMPs associated with PTBs and to provide new perspectives on the role of AMPs in PTB.
\end{abstract}

Keywords: antimicrobial peptides; preterm birth; defensin; innate immunity

\section{Introduction}

Preterm birth (PTB) refers to a multi-etiological condition that occurs in more than one out of ten child births, and approximately 1.1 million neonates die from prematurity-related complications each year [1]. Moreover, prematurity is a huge burden on the healthcare system because of long-term morbidities, such as neurodevelopmental disabilities and immediate complications related to organ system immaturity [2-6]. Approximately 70\% of PTBs occur spontaneously due to preterm labor or preterm premature rupture of membranes (PPROM), whereas medically indicated PTBs are often preceded by maternal or fetal complications, including preeclampsia or intrauterine growth restriction [7-9]. Intraamniotic infection is thought to contribute to at least one-third of spontaneous PTBs, and early gestational age is associated with a higher frequency of intra-amniotic infection [10-14]. The mechanism by which microorganisms enter the amniotic cavity is unclear. However, considering that microorganisms frequently found in intra-amniotic infection are common constituents of vaginal microbiome, intrauterine infection could often be a result of ascending infection by lower genital tract microorganisms [15-17].

The cellular structure of the reproductive tract and various immunological functions form a barrier against microbial pathogens during pregnancy. Uterine, vaginal, and cervical epithelial cells build a physical barrier by expressing intercellular junctions, including tight or occluding junctions and adherent junctions [18-21]. Furthermore, an array of immune cells is expressed in the reproductive tract to form a mucosal barrier, and mucosal epithelial and immune cells express pattern recognition receptors (PRRs) to sense and respond to pathogens [19,22-27]. In particular, the mucus plug in the cervical canal not only forms a physical barrier between the vagina (exposed to microbes) and the intrauterine space (considered "sterile") during pregnancy, but also contains various immune cells, cytokines, 
chemokines, and antimicrobial peptides (AMPs), thereby serving as an important antimicrobial barrier [28,29]. AMPs are a class of small peptides with a wide range of antimicrobial properties and are expressed throughout the female reproductive tract, including the cervix, vagina, uterine wall, amniotic fluid, fetal membranes, placenta, and fetus [30-32]. Recently, AMPs have been found to perform immunoregulatory functions through diverse mechanisms and play an essential role in maintaining immune homeostasis by interacting with the microbiome [33,34]. Several recent studies have reported an association between alterations in AMP expression and release, and infectious and inflammatory diseases, such as Crohn's disease and atopic dermatitis [35-38]. Further, recent studies have reported that alterations in AMP expression are associated with PTB. Intra-amniotic infection and inflammation are associated with higher concentrations of AMPs, and low cervicovaginal $\beta$-defensin levels in the mid-trimester were associated with a higher risk of spontaneous PTB [39-41].

Considering that intrauterine infection or inflammation and vaginal dysbiosis are some of the key triggers of PTB, AMPs may have an array of effects on PTB. Therefore, in this review, we highlight the recent findings regarding the altered expression of PTBassociated AMPs and their potential influences on the development of PTB.

\section{AMPs in PTB}

\subsection{Properties and Classification of AMPs}

AMPs are evolutionarily conserved molecules that are produced in all multicellular organisms from prokaryotes to humans, and they are the first-line defense against microbial pathogens [34,42-44]. AMPs have wide-ranging antimicrobial functions against bacteria, yeast, fungi, and viruses [33,44-46]. In higher eukaryotic organisms, AMPs also have diverse immunoregulatory activities, based on which they have also been called host defense peptides (HDPs) in recent years $[34,47,48]$. AMPs are comprised of $10-50$ amino acids with varying positive charges (from +2 to +9 ) and are amphipathic peptides with basic amino acids on one end, and hydrophobic residues on the other end, thereby constituting a unique structure that is water-soluble, positively charged, and hydrophobic [49-51]. Currently, more than 2600 natural AMPs with diverse sequences and structures are known [52]. AMPs can be broadly classified into $\alpha$-helical, $\beta$-sheet, and extended AMPs based on their secondary structure. Most AMPs belong to the $\alpha$-helical and $\beta$-sheet categories $[51,53-55]$. The two main classes of AMPs are defensins and cathelicidins. Defensins have a common $\beta$-sheet core stabilized by three disulfide bonds between six conserved cysteine residues and are classified into $\alpha-, \beta-$, and $\theta$-defensins based on the configuration of the disulfide bonds $[56,57]$. Several human $\alpha$-defensins are highly expressed in neutrophils; thus, they are known as human neutrophil peptides 1-4 (HNP1-4). HNP1-4 are stored in the azurophilic granules of neutrophils and account for $30-50 \%$ of the protein content in azurophilic granules [44,58]. Other $\alpha$-defensins are produced by Paneth cells of the small intestine (human $\alpha$-defensin 5 and 6; HD5 and HD6) [59]. Production and secretion of HNP1-3 can be upregulated by pro-inflammatory cytokines in immature monocyte-derived dendritic cells, whereas HNP1 and HD5 expressions depend on the nucleotide-binding oligomerization domain-containing protein2 (NOD2) stimulation in gut epithelial cells [55,60-62]. Human $\beta$-defensins (HBDs) are mainly produced in epithelial cells and have a protective function in sites that are exposed to microbes, such as the respiratory, intestinal, and genitourinary tracts and skin [55,63]. HBD-1 is constitutively expressed, whereas HBD-2 and HBD-3 are induced by a variety of inflammatory stimuli $[63,64]$. Cathelicidins, which are $\alpha$-helical peptides, are generally produced by epithelial cells and many immune cells. Humans have only one cathelicidin gene (CAMP) [65,66]. Cathelicidins are synthesized as a prepropeptide known as hCAP18 and can be converted into several cathelicidine peptide variants through proteolytic cleavage by various proteases, one of the most common variants being LL-37 [67]. In epithelial cells, expression of LL-37 is modulated by inflammatory stimuli; however, vitamin D also influences LL-37 expression $[65,66,68]$. Vitamin D3 directly increases hCAP18 transcription and synergizes 
with lipopolysaccharide (LPS) in LL-37 production in neutrophils. In addition, vitamin D3 plays an important role in LL-37 induction through Toll-like receptor 1 (TLR1) and TLR2 pathways during bacterial infection in monocytes and keratinocytes $[66,68]$.

\subsection{Mechanism of Action of AMPs}

\subsubsection{Antimicrobial Actions}

AMPs have direct and rapid antimicrobial activities by destroying the physical integrity of microbial membranes or by acting on intracellular targets via membrane translocation [50]. Bacterial membranes are a major target of cationic AMPs, and because bacterial membranes are negatively charged due to anionic lipids, such as phosphatidylglycerol and phosphatidylserine, they electrostatically interact with positively charged AMPs [49]. In addition, teichoic acids in the cell walls of Gram-positive bacteria and LPS in the outer membranes of Gram-negative bacteria further impart a negative charge to bacterial membranes [69]. The key mechanism of the antimicrobial action of AMPs involves the formation of an amphipathic secondary structure upon contact with cytoplasmic membranes, which ultimately leads to membrane perturbation, bacterial cell content leakage, and cell death $[70,71]$. To explain membrane perturbation by AMP, models that disrupt membranes by forming barrel-stave and toroidal pores and directly destroy the membrane by thinning and dissolving the lipid bilayer (carpet model) have been proposed. However, these models are of limited utility, as they are based on experiments that used model membranes [54,71,72]. Unlike bacteria, mammalian cell membranes generally consist of zwitterionic phospholipids and thus have a neutral net charge, wherein phospholipids with negatively charged head groups face inward $[49,73,74]$. This results in a relatively weak hydrophobic interaction with AMPs, and the high cholesterol content in mammalian cell membranes reduces AMP activity by stabilizing the phospholipid bilayer [49,75]. In addition to the antimicrobial action through membrane perturbation described above, AMPs may also exhibit antimicrobial effects by acting on intracellular targets, such as nucleic acids and proteins, through membrane translocation. Although the exact mechanism of membrane translocation by AMPs remains unknown, the involvement of inner membrane transporters or transient pores has been proposed. In addition, AMPs exhibit antiviral activity by destabilizing the viral envelope and damaging the virions, or inhibiting the viral replication of non-enveloped viruses to prevent the nuclear entry of the viral genome [76-78].

\subsubsection{Immunoregulatory Functions of AMPs}

Recent studies have demonstrated that AMPs perform a broad range of immunomodulatory functions beyond their antimicrobial activity [33]. The molecular mechanism by which AMPs regulate immune responses is highly complex, and immunomodulatory activity varies depending on the environmental stimuli, cell type, and peptide concentration [33,48]. Immunomodulatory activities of AMPs include stimulating chemotaxis of immune cells, modulating neutrophil function, and influencing adaptive immunity by recruiting antigen-presenting cells to infection sites. AMPs function as chemoattractants to stimulate chemotaxis of leukocytes by secreting chemokines $[55,63,79,80]$. In addition, AMPs regulate neutrophil functions by stimulating the release of neutrophil chemokines or increasing neutrophil influx through chemotactic functions [81,82]. AMPs are also present in neutrophil extracellular traps (NETs) and are involved in NET-mediated antibacterial effects [83]. Upon infection, AMPs recruit antigen-presenting cells, such as monocytes, macrophages, and dendritic cells, and mediate innate and adaptive immunity. AMPs exert both pro- and anti-inflammatory properties depending on the cell type and inflammatory stimuli, thereby establishing a balance of inflammation. The anti-inflammatory functions of AMPs are highlighted in studies on the association between low $\alpha$-defensin expression and ileal Crohn's disease, and in a report that a cathelicidin-knockout mouse model showed more severe inflammatory responses than the wild type [84-87]. On the other hand, cathelicidin can also promote inflammation through the induction of proinflammatory cytokines 
and chemokines or DNA- and RNA-mediated TLR activation [88-90]. Thus, overproduction of AMPs can directly trigger inflammatory diseases such as psoriasis, which highly express AMPs such as cathelicidin, $\beta$-defensins, and S100 proteins in their lesions [91].

\subsubsection{AMP-Microbiome Interaction}

There is mounting recent evidence supporting that the commensal microbiota in the body plays a pivotal role in host defense through colonization resistance and development of the mucosal immune system; thus, the balance of commensal microbiota has an impact on health and the state of disease. AMPs have both antimicrobial and immunomodulatory properties, which directly and indirectly affect the composition of commensal microbiota. A recent report showed that intestinal commensal species increase resistance to antimicrobial activities of AMPs by up to four times by reducing the overall negative charge on cell surfaces via LPS modification [92]. Moreover, it has been reported that alterations in $\alpha$-defensin expression can have a substantial impact on microbiota composition and that it manifests in association with changes in the IL-17A+CD4+ T cell count [93]. There is ongoing research on the association between vaginal dysbiosis and PTB. Although there may be variations across races, it is well known that Lactobacillus spp. (esp. Lactobacillus crispatus) dominance is associated with term birth, whereas Lactobacillus depletion, high diversity compositions, and the presence of bacterial vaginosis (BV)-associated bacteria increase the risk of PTB [94-97]. According to a recent study that investigated cervicovaginal microbiota and AMP expression, the risk of PTB can be lowered even with Mobiluncus curtsii or M. mulieris if Lactobacillus spp. relative abundance tertiles are present, but the risk of PTB is high even in the presence of Lactobacillus-spp.-dominated cervicovaginal microbiota if the $\beta$-defensin expression is low [39]. These results suggest that not only microbiome composition, but also innate immunity, including AMP action, can have a complex effect on the development of PTB. However, research on the role of AMP-microbiota interaction in PTB is still in its infancy, and further studies are needed.

\section{Expression of AMPs in Pregnancy}

AMPs, which are distributed throughout the female reproductive tract during pregnancy, play a role in preventing infection through their antimicrobial activities and modulating immune responses. HNP 1-3 were reported to be expressed in the vernix caseosa, chorion, placental trophoblasts, and amniotic fluid [41,98-102]. The levels of HNP 1-3 in the amniotic fluid are not markedly altered during pregnancy, but significantly increase during normal term parturition triggered by spontaneous labor [41]. $\beta$-defensin is widely expressed in pregnant uteri. HBD1-3 were reported to be expressed in the placenta and chorion trophoblast, amnion epithelium, and decidua, while HBD-1 and HBD-2 mRNA were expressed in the chorion, villus, and placental tissues [101-104]. The concentration of HBD-2 was not altered during pregnancy, whereas HBD-1 concentration was significantly higher in mid-pregnancy than in term $[105,106]$. High cathelicidin expression was observed in the fetal skin and vernix caseosa and within the amniotic fluid, with no marked changes in expression throughout pregnancy $[107,108]$. Lactoferrin expression has been reported in the amniotic fluid, amnion, cervix, mucus plug, and placenta [32,109]. Intra-amniotic lactoferrin concentration increased throughout pregnancy, and the lactoferrin concentration decreased in the amniotic fluid, whereas it increased in the umbilical cord plasma during spontaneous labor at term parturition. In addition, intra-amniotic infection is associated with an increased level of lactoferrin in the amniotic fluid [109,110].

\section{AMPs Associated with PTB}

In various clinical presentations related to PTB, such as preterm labor, PPROM, and cervical insufficiency, alterations in the expression of AMPs and their association with PTB have been reported. The lower female genital tract generally harbors Lactobacillusdominant commensal bacteria, which prevent the attachment and invasion of microbial pathogens [94,111]. Recent metagenomic studies have identified a unique microbiome in 
the upper female reproductive tract, including the placenta, which was previously considered sterile [112]. The cervicovaginal microbial community is classified into six community state types (CSTs), four of which are dominated by a Lactobacillus spp. (Lactobacillus crispatus (CST I), Lactobacillus gasseri (CST II), Lactobacillus iners (CST III), or Lactobacillus jensenii (CST V)). The other two (CST IV-A and CST IV-B) lack a substantial number of Lactobacillus spp. and comprise a diverse array of anaerobic bacteria $[113,114]$. A healthy pregnancy is characterized by a shift to a less diverse and more Lactobacillus dominant CST [113]. Recent studies have shown that Lactobacillus iners-dominant vaginal communities (CST III) are associated with PTB, and vaginal dysbiosis characterized by lower levels of Lactobacillus spp. and high species diversity, as in BV, has been associated with increased risk of PPROM, PTB, and histologic chorioamnionitis $[39,94,115,116]$. BV and other reproductive tract infections are common during pregnancy, but PTB occurs only in certain subgroups, implying that PTB is affected by various factors, such as host defense mechanisms, in addition to the microbial pathogen. Balu et al. reported that women with intermediate BV at 24-29 weeks' gestation were more likely to have higher vaginal fluid neutrophil defensin concentration, and women with elevated vaginal fluid neutrophil defensin concentration during mid-pregnancy had an increased risk for delivery before 32 weeks. However, elevated vaginal fluid neutrophil defensin concentration was not associated with PTB before 37 weeks [117]. Further, BV at $<16$ weeks' gestation was associated with lower vaginal $\beta$-defensin 3 concentrations, but not HBD-2 or HNP 1-3 in African American-majority participants [118]. The association of HNP 3 levels and BV with PTB differed by race group: high vaginal HNP 1-3 levels at mid-pregnancy were associated with PTB in African American women, but vaginal HNP 1-3 levels were not related to PTB in non-Hispanic Whites [119]. In addition, a recent study reported that concentrations of cervicovaginal fluid cathelicidin and human neutrophil elastase at 10-24 weeks' gestation were increased in women with cervical shortening and were predictive of PTB before 37 weeks, whereas another study demonstrated that higher vaginal $\beta$-defensin 2 levels were associated with a lower risk of PTB $[39,120]$. Moreover, in this study, even in Lactobacillus spp.-dominant cervicovaginal microbiota, low $\beta$-defensin 2 levels were associated with a higher risk of PTB [39]. In addition, a study on the association of maternal stress during pregnancy and PTB found that high stress was related to low cervicovaginal $\beta$-defensin 2 levels, and high stress and low cervicovaginal $\beta$-defensin 2 levels were risk factors for PTB [121]. The results of studies on alterations in the vaginal fluid AMP expression according to BV or the association between the AMP expression and the risk of PTB are inconsistent, which is attributable to differences in the type of AMPs, gestational weeks of sample collection, clinical features related to PTB, and ethnicity.

The HNP1-3 concentration in the amniotic fluid significantly increased in women with preterm labor with intra-amniotic infection, and HNP1-3 expression was markedly upregulated in women with PPROM [41]. In addition, the concentration of amniotic fluid HNP1-3 increased during both term parturition and PTB, and high concentration of amniotic fluid HNP1-3 was associated with intra-amniotic inflammation and histological chorioamnionitis in women with preterm labor, leading to PTB [41]. Moreover, amniotic fluid HNP1-3 levels increased markedly in women with subclinical intrauterine infection and exponentially according to the severity of histologic chorioamnionitis [98]. Several recent studies have revealed amniotic fluid $\beta$-defensin expression during normal pregnancy and changes in expression when intra-amniotic infection/inflammation or PPROM occurs. HBD-1 expression in the amniotic fluid is higher in the mid-trimester than in term, and HBD-1 expression is increased in women with intra-amniotic inflammation compared to those without intra-amniotic inflammation [106]. The HBD-2 concentration in the amniotic fluid did not change throughout the pregnancy and was markedly increased in women with intra-amniotic infection. Patients with preterm labor who delivered preterm had higher amniotic fluid HBD-2 concentrations than those who delivered at term. Further, HBD-2 expression was higher in women with intra-amniotic inflammation than in those without intra-amniotic inflammation [105]. Similar to HBD-2, the intra-amniotic concentration 
of HBD-3 also did not change throughout pregnancy, and women with spontaneous labor at term showed higher HBD-3 expression than those without labor. Moreover, HBD-3 levels were higher in women with intra-amniotic infection who delivered preterm due to preterm labor than in those who did not have an intra-amniotic infection. In women with PPROM, amniotic fluid HBD-3 concentrations were higher in women with PPROM and intra-amniotic infection than in those without intra-amniotic infection [40]. In addition, it was reported that cathelicidin may be used as a candidate marker to identify the presence of intra-amniotic infection in women with PPROM, since the level of cathelicidin in the amniotic fluid increases in the presence of intra-amniotic infection in PPROM patients [122]. In an experimental study using amnion epithelial cells, treating cells with LPS led to a marked upregulation of HBD-3 mRNA expression, and the HBD-3 protein in the amnion sections was intensively positive in women with histological chorioamnionitis who delivered preterm compared to the control patients who delivered at term [123]. Moreover, exposure of the amniotic membrane to IL-1 $\beta$ leads to increased secretion of AMPs, including HBD-2, HBD-3, cathelicidin, and elafin [124,125]. These results indicate that amnion epithelial cells can produce defensins in the amniotic fluid in response to infection or inflammatory stimuli and contribute to the innate immunity of the intraamniotic cavity. The previously described alterations in the expression of AMPs associated with PTB are summarized in Table 1.

Table 1. Summary of the expression of AMPs associated with preterm birth.

\begin{tabular}{|c|c|c|c|c|c|}
\hline AMPs & Gene & Site of Expression & $\begin{array}{l}\text { Gestational } \\
\text { Weeks of Sample } \\
\text { Collection }\end{array}$ & $\begin{array}{c}\text { Expression Associated } \\
\text { with PTB }\end{array}$ & References \\
\hline \multirow[t]{5}{*}{ HNP 1-3 } & DEFA1,3 & Vagina & $24-29$ & $\begin{array}{c}\text { PTB }<32 \text { weeks } \uparrow \\
\mathrm{PTB}<37 \text { weeks } \leftrightarrow\end{array}$ & [117] \\
\hline & & & Mid-pregnancy & $\begin{array}{c}\text { PTB } \uparrow \text { in African American } \\
\text { PTB } \leftrightarrow \text { in non-Hispanic } \\
\text { Whites }\end{array}$ & [119] \\
\hline & & Amniotic fluid & $19-33$ & $\begin{array}{c}\text { Intra-amniotic infection } \uparrow \\
\text { PPROM } \uparrow \\
\text { Preterm parturition } \uparrow\end{array}$ & [41] \\
\hline & & & $24-34$ & $\begin{array}{l}\text { Subclinical intrauterine } \\
\text { infection } \uparrow\end{array}$ & [98] \\
\hline & & Fetal membranes & $23-33$ & $\begin{array}{c}\text { Histologic chorioamnionitis } \uparrow \\
\text { PPROM } \uparrow\end{array}$ & [126] \\
\hline \multicolumn{6}{|l|}{ Beta-defensins } \\
\hline HBD-1 & DEFB1 & Amniotic fluid & $20-32$ & $\mathrm{IAI} \uparrow$ & [106] \\
\hline \multirow[t]{2}{*}{ HBD-2 } & DEFB2 & Vagina & $16-28$ & PTB $<37$ weeks $\downarrow$ & [39] \\
\hline & & Amniotic fluid & $20-32$ & $\begin{array}{c}\text { Intra-amniotic infection } \uparrow \\
\text { IAI } \uparrow \\
\text { Preterm delivery } \uparrow\end{array}$ & [105] \\
\hline HBD-3 & DEFB3 & Amniotic fluid & $20-32$ & Intra-amniotic infection $\uparrow$ & [40] \\
\hline \multirow[t]{2}{*}{ Cathelicidin } & CAMP & Vagina & $10-24$ & $\begin{array}{l}\text { Cervical shortening } \uparrow \\
\text { PTB }<37 \text { weeks } \uparrow\end{array}$ & [120] \\
\hline & & Amniotic fluid & $24-34$ & $\begin{array}{c}\text { PPROM with Intra-amniotic } \\
\text { infection } \uparrow\end{array}$ & [122] \\
\hline
\end{tabular}

Abbreviations: HNP, human neutrophil peptides; PTB, preterm birth; PPROM, preterm premature rupture of membranes; HBD, human $\beta$-defensin; IAI, intra-amniotic inflammation; $\uparrow$, increased; $\leftrightarrow$, not changed; $\downarrow$, decreased.

In fetal membranes, $\alpha$-defensin 1 mRNA expression was markedly upregulated in the presence of histologic chorioamnionitis, and among those with histologic chorioamnionitis, 
$\alpha$-defensin 1 mRNA expression was significantly higher in those with preterm labor with intact membranes than in those with PPROM [126]. In addition, HBD1-3 and elafin were present in the placenta and fetal membranes, and HBD-2 and elafin mRNA expressions were increased by proinflammatory cytokines in primary trophoblast cells [127]. These results suggest that AMPs in the placenta and fetal membranes also act as an immunologic barrier against infection by regulating their expression during pregnancy.

A recent whole-exome sequencing study identified rare mutations in genes encoding antimicrobial peptides / proteins ( $\beta$-defensin 1 [DEFB1] and mannose-binding lectin [MBL2]) that were more frequent in neonates born to pregnancies complicated by PPROM $[128,129]$. Moreover, these genes have been previously linked to inflammatory bowel diseases and periodontal diseases. These inflammatory conditions have been reported to be associated with PTB, and alterations in AMP expression have been found to play an important role in the development of these inflammatory diseases. Therefore, these results suggest that mutations and damaging missense variants in the innate immunity or host defense genes may be associated with an increased risk of PTB. In addition, a recent RNA sequencing analysis revealed that women with cervical dilation at mid-pregnancy have markedly higher $\alpha$-defensin 3 (DEFA3) gene and $\alpha$-defensin 3 protein expression in blood compared to the normal group [130]. These findings suggest that $\alpha$-defensin plays an important role in preventing microbial infection and inflammation in cervical insufficiency, where the mechanical and immunologic barrier of the cervix is disrupted. Moreover, among women with cervical dilation, downregulated DEFA3 gene expression at mid-pregnancy was prospectively associated with PTB. These findings seemed to contradict the results of previous studies that intra-amniotic inflammation/infection and preterm labor are associated with high defensin levels. However, considering that defensin deficiency is involved in the development of Crohn's disease, and defensin functions as an immune response modulator through both pro-and anti-inflammatory properties, it is suggested that the differential expression of defensins, according to the severity of the infection and inflammatory response, can affect the pregnancy prognosis. Moreover, this tendency has also been observed in other recent studies. Low levels of $\beta$-defensin 2 were associated with an increased risk of PTB, and high maternal stress lowered $\beta$-defensin 2 levels, each of which increased the risk of PTB $[39,121]$. Taken together, these results suggested that the expression of AMPs increases when an inflammatory response such as intraamniotic infection, PPROM, or cervical dilation occurs, but the expression of AMPs before the onset of symptoms may prospectively affect the development and progression of preterm parturition.

\section{Conclusions and Future Perspectives}

Several studies on significant alterations in the expression of AMPs in PTB-associated clinical presentations and correlation of the level of AMP expression with pregnancy prognosis suggest that AMPs play an important role in the development of PTB.

In view of the complex host defense properties of AMPs, such as antimicrobial and immunomodulatory properties and shaping of the composition of the commensal microbiota, many AMP-based therapeutic agents have recently been investigated, not only as new anti-infectives that can overcome the limitations of antibiotics related to drug-resistant pathogens, but also as immunomodulatory agents in a variety of indications, such as chronic inflammatory disorders and wound healing. As infections and microbial dysbiosis emerge as common causes of PTB, further research on functions and mechanisms of action of AMPs may enhance our understanding of the pathogenesis of PTB and provide promising treatment options.

Author Contributions: Conceptualization, G.-H.S., Y.K. and J.-J.L.; validation, J.-J.L. and K.-Y.L.; writing-original draft preparation, G.-H.S. and Y.K.; writing-review and editing, G.-H.S., Y.K., J.-J.L. and K.-Y.L.; supervision, K.-Y.L.; funding acquisition, G.-H.S. All authors have read and agreed to the published version of the manuscript. 
Funding: This research was supported by a grant of the Korea Health Technology R\&D Project through the Korea Health Industry Development Institute (KHIDI), funded by the Ministry Of Health \& Welfare, Republic of Korea (grant number: HI21C1624), and Hallym University Research Fund 2021 (HURF-2021-05).

Institutional Review Board Statement: Not applicable.

Informed Consent Statement: Not applicable.

Conflicts of Interest: The authors declare no conflict of interest.

\section{References}

1. Iams, J.D. Clinical practice. Prevention of preterm parturition. N. Engl. J. Med. 2014, 370, 254-261. [CrossRef] [PubMed]

2. Liu, L.; Chu, Y.; Oza, S.; Hogan, D.; Perin, J.; Bassani, D.G.; Ram, U.; Fadel, S.A.; Pandey, A.; Dhingra, N.; et al. National, regional, and state-level all-cause and cause-specific under-5 mortality in india in 2000-15: A systematic analysis with implications for the sustainable development goals. Lancet Glob. Health 2019, 7, e721-e734. [CrossRef]

3. Murray, C.J.; Vos, T.; Lozano, R.; Naghavi, M.; Flaxman, A.D.; Michaud, C.; Ezzati, M.; Shibuya, K.; Salomon, J.A.; Abdalla, S.; et al. Disability-adjusted life years (dalys) for 291 diseases and injuries in 21 regions, 1990-2010: A systematic analysis for the global burden of disease study 2010. Lancet 2012, 380, 2197-2223. [CrossRef]

4. Mwaniki, M.K.; Atieno, M.; Lawn, J.E.; Newton, C.R. Long-term neurodevelopmental outcomes after intrauterine and neonatal insults: A systematic review. Lancet 2012, 379, 445-452. [CrossRef]

5. Stoll, B.J.; Hansen, N.I.; Adams-Chapman, I.; Fanaroff, A.A.; Hintz, S.R.; Vohr, B.; Higgins, R.D. Neurodevelopmental and growth impairment among extremely low-birth-weight infants with neonatal infection. JAMA 2004, 292, 2357-2365. [CrossRef]

6. MacKay, D.F.; Smith, G.C.; Dobbie, R.; Pell, J.P. Gestational age at delivery and special educational need: Retrospective cohort study of 407,503 schoolchildren. PLoS Med. 2010, 7, e1000289. [CrossRef] [PubMed]

7. Stout, M.J.; Busam, R.; Macones, G.A.; Tuuli, M.G. Spontaneous and indicated preterm birth subtypes: Interobserver agreement and accuracy of classification. Am. J. Obstet. Gynecol. 2014, 211, 530.e1-530.e4. [CrossRef]

8. Wong, A.E.; Grobman, W.A. Medically indicated-Iatrogenic prematurity. Clin. Perinatol. 2011, 38, 423-439. [CrossRef]

9. Moutquin, J.M. Classification and heterogeneity of preterm birth. BJOG 2003, 110, 30-33. [CrossRef]

10. Kim, C.J.; Romero, R.; Chaemsaithong, P.; Kim, J.S. Chronic inflammation of the placenta: Definition, classification, pathogenesis, and clinical significance. Am. J. Obstet. Gynecol. 2015, 213, S53-S69. [CrossRef]

11. Kim, C.J.; Romero, R.; Kusanovic, J.P.; Yoo, W.; Dong, Z.; Topping, V.; Gotsch, F.; Yoon, B.H.; Chi, J.G.; Kim, J.S. The frequency, clinical significance, and pathological features of chronic chorioamnionitis: A lesion associated with spontaneous preterm birth. Mod. Pathol. 2010, 23, 1000-1011. [CrossRef]

12. Klein, L.L.; Gibbs, R.S. Infection and preterm birth. Obstet. Gynecol. Clin. N. Am. 2005, 32, 397-410. [CrossRef]

13. Combs, C.A.; Gravett, M.; Garite, T.J.; Hickok, D.E.; Lapidus, J.; Porreco, R.; Rael, J.; Grove, T.; Morgan, T.K.; Clewell, W.; et al. Amniotic fluid infection, inflammation, and colonization in preterm labor with intact membranes. Am. J. Obstet. Gynecol. 2014, 210, 125.e1-125.e15. [CrossRef]

14. Kim, C.J.; Romero, R.; Chaemsaithong, P.; Chaiyasit, N.; Yoon, B.H.; Kim, Y.M. Acute chorioamnionitis and funisitis: Definition, pathologic features, and clinical significance. Am. J. Obstet. Gynecol. 2015, 213, S29-S52. [CrossRef] [PubMed]

15. Goldenberg, R.L.; Hauth, J.C.; Andrews, W.W. Intrauterine infection and preterm delivery. N. Engl. J. Med. 2000, 342, 1500-1507. [CrossRef]

16. Martin, D.H. The microbiota of the vagina and its influence on women's health and disease. Am. J. Med. Sci. 2012, 343, 2-9. [CrossRef] [PubMed]

17. Kim, N.K.; Choi, Y.J.; Hong, S.; Park, J.Y.; Oh, K.J.; Hong, J.S. Subsequent pregnancy outcomes according to the presence of acute histologic chorioamnionitis in women with spontaneous preterm delivery. Obstet. Gynecol. Sci. 2020, 63, 126-132. [CrossRef] [PubMed]

18. Quayle, A.J. The innate and early immune response to pathogen challenge in the female genital tract and the pivotal role of epithelial cells. J. Reprod. Immunol. 2002, 57, 61-79. [CrossRef]

19. Wira, C.R.; Fahey, J.V.; Sentman, C.L.; Pioli, P.A.; Shen, L. Innate and adaptive immunity in female genital tract: Cellular responses and interactions. Immunol. Rev. 2005, 206, 306-335. [CrossRef]

20. Hjelm, B.E.; Berta, A.N.; Nickerson, C.A.; Arntzen, C.J.; Herbst-Kralovetz, M.M. Development and characterization of a threedimensional organotypic human vaginal epithelial cell model. Biol. Reprod. 2010, 82, 617-627. [CrossRef]

21. Blaskewicz, C.D.; Pudney, J.; Anderson, D.J. Structure and function of intercellular junctions in human cervical and vaginal mucosal epithelia. Biol. Reprod. 2011, 85, 97-104. [CrossRef] [PubMed]

22. Yang, Z.; Kong, B.; Mosser, D.M.; Zhang, X. Tlrs, macrophages, and nk cells: Our understandings of their functions in uterus and ovary. Int. Immunopharmacol. 2011, 11, 1442-1450. [CrossRef]

23. Aflatoonian, R.; Fazeli, A. Toll-like receptors in female reproductive tract and their menstrual cycle dependent expression. J. Reprod. Immunol. 2008, 77, 7-13. [CrossRef] [PubMed] 
24. Yu, L.; Wang, L.; Chen, S. Toll-like receptors, inflammation and tumor in the human female reproductive tract. Am. J. Reprod. Immunol. 2009, 62, 1-8. [CrossRef] [PubMed]

25. Park, S.; You, Y.A.; Yun, H.; Choi, S.J.; Hwang, H.S.; Choi, S.K.; Lee, S.M.; Kim, Y.J. Cervicovaginal fluid cytokines as predictive markers of preterm birth in symptomatic women. Obstet. Gynecol. Sci. 2020, 63, 455-463. [CrossRef] [PubMed]

26. Monin, L.; Whettlock, E.M.; Male, V. Immune responses in the human female reproductive tract. Immunology 2020, 160, 106-115. [CrossRef]

27. Mei, C.; Yang, W.; Wei, X.; Wu, K.; Huang, D. The unique microbiome and innate immunity during pregnancy. Front. Immunol. 2019, 10, 2886. [CrossRef] [PubMed]

28. Becher, N.; Adams Waldorf, K.; Hein, M.; Uldbjerg, N. The cervical mucus plug: Structured review of the literature. Acta Obstet. Gynecol. Scand. 2009, 88, 502-513. [CrossRef]

29. Radtke, A.L.; Quayle, A.J.; Herbst-Kralovetz, M.M. Microbial products alter the expression of membrane-associated mucin and antimicrobial peptides in a three-dimensional human endocervical epithelial cell model. Biol. Reprod. 2012, 87, 132. [CrossRef]

30. Yarbrough, V.L.; Winkle, S.; Herbst-Kralovetz, M.M. Antimicrobial peptides in the female reproductive tract: A critical component of the mucosal immune barrier with physiological and clinical implications. Hum. Reprod. Update 2015, 21, 353-377. [CrossRef]

31. Frew, L.; Stock, S.J. Antimicrobial peptides and pregnancy. Reproduction 2011, 141, 725-735. [CrossRef]

32. Hein, M.; Valore, E.V.; Helmig, R.B.; Uldbjerg, N.; Ganz, T. Antimicrobial factors in the cervical mucus plug. Am. J. Obstet. Gynecol. 2002, 187, 137-144. [CrossRef] [PubMed]

33. Hancock, R.E.; Haney, E.F.; Gill, E.E. The immunology of host defence peptides: Beyond antimicrobial activity. Nat. Rev. Immunol. 2016, 16, 321-334. [CrossRef] [PubMed]

34. Mookherjee, N.; Anderson, M.A.; Haagsman, H.P.; Davidson, D.J. Antimicrobial host defence peptides: Functions and clinical potential. Nat. Rev. Drug Discov. 2020, 19, 311-332. [CrossRef] [PubMed]

35. Clausen, M.L.; Slotved, H.C.; Krogfelt, K.A.; Andersen, P.S.; Agner, T. In vivo expression of antimicrobial peptides in atopic dermatitis. Exp. Dermatol. 2016, 25, 3-9. [CrossRef] [PubMed]

36. Harder, J.; Dressel, S.; Wittersheim, M.; Cordes, J.; Meyer-Hoffert, U.; Mrowietz, U.; Fölster-Holst, R.; Proksch, E.; Schröder, J.M.; Schwarz, T.; et al. Enhanced expression and secretion of antimicrobial peptides in atopic dermatitis and after superficial skin injury. J. Investig. Dermatol. 2010, 130, 1355-1364. [CrossRef]

37. Kopfnagel, V.; Harder, J.; Werfel, T. Expression of antimicrobial peptides in atopic dermatitis and possible immunoregulatory functions. Curr. Opin. Allergy Clin. Immunol. 2013, 13, 531-536. [CrossRef]

38. Gallo, R.L.; Hooper, L.V. Epithelial antimicrobial defence of the skin and intestine. Nat. Rev. Immunol. 2012, 12, 503-516. [CrossRef]

39. Elovitz, M.A.; Gajer, P.; Riis, V.; Brown, A.G.; Humphrys, M.S.; Holm, J.B.; Ravel, J. Cervicovaginal microbiota and local immune response modulate the risk of spontaneous preterm delivery. Nat. Commun. 2019, 10, 1305. [CrossRef]

40. Para, R.; Romero, R.; Miller, D.; Panaitescu, B.; Varrey, A.; Chaiworapongsa, T.; Hassan, S.S.; Hsu, C.D.; Gomez-Lopez, N. Human $\beta$-defensin-3 participates in intra-amniotic host defense in women with labor at term, spontaneous preterm labor and intact membranes, and preterm prelabor rupture of membranes. J. Matern. Fetal Neonatal. Med. 2020, 33, 4117-4132. [CrossRef]

41. Espinoza, J.; Chaiworapongsa, T.; Romero, R.; Edwin, S.; Rathnasabapathy, C.; Gomez, R.; Bujold, E.; Camacho, N.; Kim, Y.M.; Hassan, S.; et al. Antimicrobial peptides in amniotic fluid: Defensins, calprotectin and bacterial/permeability-increasing protein in patients with microbial invasion of the amniotic cavity, intra-amniotic inflammation, preterm labor and premature rupture of membranes. J. Matern. Fetal Neonatal Med. 2003, 13, 2-21. [CrossRef] [PubMed]

42. Mahlapuu, M.; Håkansson, J.; Ringstad, L.; Björn, C. Antimicrobial peptides: An emerging category of therapeutic agents. Front. Cell Infect. Microbiol. 2016, 6, 194. [CrossRef]

43. Hancock, R.E. Cationic antimicrobial peptides: Towards clinical applications. Expert Opin. Investig. Drugs 2000, 9, 1723-1729. [CrossRef] [PubMed]

44. Ganz, T. Defensins: Antimicrobial peptides of innate immunity. Nat. Rev. Immunol. 2003, 3, 710-720. [CrossRef] [PubMed]

45. Marr, A.K.; Gooderham, W.J.; Hancock, R.E. Antibacterial peptides for therapeutic use: Obstacles and realistic outlook. Curr. Opin. Pharmacol. 2006, 6, 468-472. [CrossRef]

46. Reddy, K.V.; Yedery, R.D.; Aranha, C. Antimicrobial peptides: Premises and promises. Int. J. Antimicrob. Agents 2004, $24,536-547$. [CrossRef]

47. Hemshekhar, M.; Anaparti, V.; Mookherjee, N. Functions of cationic host defense peptides in immunity. Pharmaceuticals 2016, 9, 40. [CrossRef]

48. Van der Does, A.M.; Hiemstra, P.S.; Mookherjee, N. Antimicrobial host defence peptides: Immunomodulatory functions and translational prospects. Adv. Exp. Med. Biol. 2019, 1117, 149-171.

49. Yeaman, M.R.; Yount, N.Y. Mechanisms of antimicrobial peptide action and resistance. Pharmacol. Rev. 2003, 55, 27-55. [CrossRef]

50. Hancock, R.E.; Sahl, H.G. Antimicrobial and host-defense peptides as new anti-infective therapeutic strategies. Nat. Biotechnol. 2006, 24, 1551-1557. [CrossRef]

51. Pasupuleti, M.; Schmidtchen, A.; Malmsten, M. Antimicrobial peptides: Key components of the innate immune system. Crit. Rev. Biotechnol. 2012, 32, 143-171. [CrossRef]

52. Wang, G.; Li, X.; Wang, Z. Apd3: The antimicrobial peptide database as a tool for research and education. Nucleic Acids Res. 2016, 44, D1087-D1093. [CrossRef] [PubMed] 
53. Takahashi, D.; Shukla, S.K.; Prakash, O.; Zhang, G. Structural determinants of host defense peptides for antimicrobial activity and target cell selectivity. Biochimie 2010, 92, 1236-1241. [CrossRef] [PubMed]

54. Nguyen, L.T.; Haney, E.F.; Vogel, H.J. The expanding scope of antimicrobial peptide structures and their modes of action. Trends Biotechnol. 2011, 29, 464-472. [CrossRef]

55. Hazlett, L.; Wu, M. Defensins in innate immunity. Cell Tissue Res. 2011, 343, 175-188. [CrossRef]

56. Powers, J.P.; Hancock, R.E. The relationship between peptide structure and antibacterial activity. Peptides 2003, 24, 1681-1691. [CrossRef]

57. Yount, N.Y.; Bayer, A.S.; Xiong, Y.Q.; Yeaman, M.R. Advances in antimicrobial peptide immunobiology. Biopolymers 2006, 84, 435-458. [CrossRef]

58. Ganz, T.; Selsted, M.E.; Szklarek, D.; Harwig, S.S.; Daher, K.; Bainton, D.F.; Lehrer, R.I. Defensins. Natural peptide antibiotics of human neutrophils. J. Clin. Investig. 1985, 76, 1427-1435. [CrossRef] [PubMed]

59. Bevins, C.L.; Salzman, N.H. Paneth cells, antimicrobial peptides and maintenance of intestinal homeostasis. Nat. Rev. MicroBiol. 2011, 9, 356-368. [CrossRef] [PubMed]

60. Rodríguez-García, M.; Oliva, H.; Climent, N.; García, F.; Gatell, J.M.; Gallart, T. Human immature monocyte-derived dendritic cells produce and secrete alpha-defensins 1-3. J. Leukoc. Biol. 2007, 82, 1143-1146. [CrossRef]

61. Yamamoto-Furusho, J.K.; Barnich, N.; Hisamatsu, T.; Podolsky, D.K. Mdp-nod2 stimulation induces hnp-1 secretion, which contributes to nod2 antibacterial function. Inflamm. Bowel Dis. 2010, 16, 736-742. [CrossRef]

62. Negroni, A.; Stronati, L.; Pierdomenico, M.; Tirindelli, D.; Di Nardo, G.; Mancini, V.; Maiella, G.; Cucchiara, S. Activation of nod2-mediated intestinal pathway in a pediatric population with crohn's disease. Inflamm. Bowel Dis. 2009, 15, 1145-1154. [CrossRef] [PubMed]

63. Semple, F.; Dorin, J.R. B-defensins: Multifunctional modulators of infection, inflammation and more? J. Innate Immun. 2012, 4, 337-348. [CrossRef]

64. Harder, J.; Bartels, J.; Christophers, E.; Schroder, J.M. Isolation and characterization of human beta -defensin-3, a novel human inducible peptide antibiotic. J. Biol. Chem. 2001, 276, 5707-5713. [CrossRef]

65. Vandamme, D.; Landuyt, B.; Luyten, W.; Schoofs, L. A comprehensive summary of 11-37, the factotum human cathelicidin peptide. Cell Immunol. 2012, 280, 22-35. [CrossRef] [PubMed]

66. Nijnik, A.; Hancock, R.E. The roles of cathelicidin 1l-37 in immune defences and novel clinical applications. Curr. Opin. Hematol. 2009, 16, 41-47. [CrossRef] [PubMed]

67. Murakami, M.; Lopez-Garcia, B.; Braff, M.; Dorschner, R.A.; Gallo, R.L. Postsecretory processing generates multiple cathelicidins for enhanced topical antimicrobial defense. J. Immunol. 2004, 172, 3070-3077. [CrossRef] [PubMed]

68. Wang, T.T.; Nestel, F.P.; Bourdeau, V.; Nagai, Y.; Wang, Q.; Liao, J.; Tavera-Mendoza, L.; Lin, R.; Hanrahan, J.W.; Mader, S.; et al. Cutting edge: 1,25-dihydroxyvitamin $\mathrm{d} 3$ is a direct inducer of antimicrobial peptide gene expression. J. Immunol. 2004, 173, 2909-2912. [CrossRef]

69. Yeung, A.T.; Gellatly, S.L.; Hancock, R.E. Multifunctional cationic host defence peptides and their clinical applications. Cell Mol. Life Sci. 2011, 68, 2161-2176. [CrossRef]

70. Sochacki, K.A.; Barns, K.J.; Bucki, R.; Weisshaar, J.C. Real-time attack on single escherichia coli cells by the human antimicrobial peptide 11-37. Proc. Natl. Acad. Sci. USA 2011, 108, E77-E81. [CrossRef]

71. Jenssen, H.; Hamill, P.; Hancock, R.E. Peptide antimicrobial agents. Clin. MicroBiol. Rev. 2006, 19, 491-511. [CrossRef] [PubMed]

72. Brogden, K.A. Antimicrobial peptides: Pore formers or metabolic inhibitors in bacteria? Nat. Rev. MicroBiol. 2005, 3, 238-250. [CrossRef] [PubMed]

73. Ebenhan, T.; Gheysens, O.; Kruger, H.G.; Zeevaart, J.R.; Sathekge, M.M. Antimicrobial peptides: Their role as infection-selective tracers for molecular imaging. Biomed Res. Int. 2014, 2014, 867381. [CrossRef]

74. Zasloff, M. Antimicrobial peptides of multicellular organisms. Nature 2002, 415, 389-395. [CrossRef]

75. Lai, Y.; Gallo, R.L. Amped up immunity: How antimicrobial peptides have multiple roles in immune defense. Trends Immunol. 2009, 30, 131-141. [CrossRef] [PubMed]

76. Tripathi, S.; Verma, A.; Kim, E.J.; White, M.R.; Hartshorn, K.L. Ll-37 modulates human neutrophil responses to influenza a virus J. Leukoc. Biol. 2014, 96, 931-938. [CrossRef]

77. Kota, S.; Sabbah, A.; Chang, T.H.; Harnack, R.; Xiang, Y.; Meng, X.; Bose, S. Role of human beta-defensin-2 during tumor necrosis factor-alpha/nf-kappab-mediated innate antiviral response against human respiratory syncytial virus. J. Biol. Chem. 2008, 283, 22417-22429. [CrossRef]

78. Brice, D.C.; Toth, Z.; Diamond, G. L1-37 disrupts the kaposi's sarcoma-associated herpesvirus envelope and inhibits infection in oral epithelial cells. Antiviral. Res. 2018, 158, 25-33. [CrossRef]

79. Yang, D.; Chen, Q.; Chertov, O.; Oppenheim, J.J. Human neutrophil defensins selectively chemoattract naive $t$ and immature dendritic cells. J. Leukoc. Biol. 2000, 68, 9-14.

80. Tjabringa, G.S.; Ninaber, D.K.; Drijfhout, J.W.; Rabe, K.F.; Hiemstra, P.S. Human cathelicidin 1l-37 is a chemoattractant for eosinophils and neutrophils that acts via formyl-peptide receptors. Int. Arch. Allergy Immunol. 2006, 140, 103-112. [CrossRef]

81. Hemshekhar, M.; Choi, K.G.; Mookherjee, N. Host defense peptide 11-37-mediated chemoattractant properties, but not antiinflammatory cytokine il-1ra production, is selectively controlled by cdc42 rho gtpase via g protein-coupled receptors and jnk mitogen-activated protein kinase. Front. Immunol. 2018, 9, 1871. [CrossRef] [PubMed] 
82. Zheng, Y.; Niyonsaba, F.; Ushio, H.; Nagaoka, I.; Ikeda, S.; Okumura, K.; Ogawa, H. Cathelicidin ll-37 induces the generation of reactive oxygen species and release of human alpha-defensins from neutrophils. Br. J. Dermatol. 2007, 157, 1124-1131. [CrossRef] [PubMed]

83. Stephan, A.; Batinica, M.; Steiger, J.; Hartmann, P.; Zaucke, F.; Bloch, W.; Fabri, M. L137:DNA complexes provide antimicrobial activity against intracellular bacteria in human macrophages. Immunology 2016, 148, 420-432. [CrossRef] [PubMed]

84. Wehkamp, J.; Schmid, M.; Stange, E.F. Defensins and other antimicrobial peptides in inflammatory bowel disease. Curr. Opin. Gastroenterol. 2007, 23, 370-378. [CrossRef] [PubMed]

85. Nizet, V.; Ohtake, T.; Lauth, X.; Trowbridge, J.; Rudisill, J.; Dorschner, R.A.; Pestonjamasp, V.; Piraino, J.; Huttner, K.; Gallo, R.L. Innate antimicrobial peptide protects the skin from invasive bacterial infection. Nature 2001, 414, 454-457. [CrossRef]

86. Severino, P.; Ariga, S.K.; Barbeiro, H.V.; de Lima, T.M.; de Paula Silva, E.; Barbeiro, D.F.; Machado, M.C.C.; Nizet, V.; Pinheiro da Silva, F. Cathelicidin-deficient mice exhibit increased survival and upregulation of key inflammatory response genes following cecal ligation and puncture. J. Mol. Med. 2017, 95, 995-1003. [CrossRef]

87. Wehkamp, J.; Schmid, M.; Fellermann, K.; Stange, E.F. Defensin deficiency, intestinal microbes, and the clinical phenotypes of crohn's disease. J. Leukoc. Biol. 2005, 77, 460-465. [CrossRef] [PubMed]

88. Alalwani, S.M.; Sierigk, J.; Herr, C.; Pinkenburg, O.; Gallo, R.; Vogelmeier, C.; Bals, R. The antimicrobial peptide ll-37 modulates the inflammatory and host defense response of human neutrophils. Eur. J. Immunol. 2010, 40, 1118-1126. [CrossRef]

89. Scheenstra, M.R.; van Harten, R.M.; Veldhuizen, E.J.A.; Haagsman, H.P.; Coorens, M. Cathelicidins modulate tlr-activation and inflammation. Front. Immunol. 2020, 11, 1137. [CrossRef]

90. Van Harten, R.M.; van Woudenbergh, E.; van Dijk, A.; Haagsman, H.P. Cathelicidins: Immunomodulatory antimicrobials. Vaccines 2018, 6, 63. [CrossRef]

91. Takahashi, T.; Yamasaki, K. Psoriasis and antimicrobial peptides. Int. J. Mol. Sci. 2020, 21, 6791. [CrossRef]

92. Cullen, T.W.; Schofield, W.B.; Barry, N.A.; Putnam, E.E.; Rundell, E.A.; Trent, M.S.; Degnan, P.H.; Booth, C.J.; Yu, H.; Goodman, A.L. Gut microbiota. Antimicrobial peptide resistance mediates resilience of prominent gut commensals during inflammation. Science 2015, 347, 170-175. [CrossRef]

93. Salzman, N.H.; Hung, K.; Haribhai, D.; Chu, H.; Karlsson-Sjöberg, J.; Amir, E.; Teggatz, P.; Barman, M.; Hayward, M.; Eastwood, D.; et al. Enteric defensins are essential regulators of intestinal microbial ecology. Nat. Immunol. 2010, 11, 76-83. [CrossRef]

94. Bayar, E.; Bennett, P.R.; Chan, D.; Sykes, L.; MacIntyre, D.A. The pregnancy microbiome and preterm birth. Semin. Immunopathol. 2020, 42, 487-499. [CrossRef] [PubMed]

95. Fettweis, J.M.; Serrano, M.G.; Brooks, J.P.; Edwards, D.J.; Girerd, P.H.; Parikh, H.I.; Huang, B.; Arodz, T.J.; Edupuganti, L.; Glascock, A.L.; et al. The vaginal microbiome and preterm birth. Nat. Med. 2019, 25, 1012-1021. [CrossRef] [PubMed]

96. Al-Nasiry, S.; Ambrosino, E.; Schlaepfer, M.; Morré, S.A.; Wieten, L.; Voncken, J.W.; Spinelli, M.; Mueller, M.; Kramer, B.W. The interplay between reproductive tract microbiota and immunological system in human reproduction. Front. Immunol. 2020, 11, 378. [CrossRef]

97. Tsonis, O.; Gkrozou, F.; Harrison, E.; Stefanidis, K.; Vrachnis, N.; Paschopoulos, M. Female genital tract microbiota affecting the risk of preterm birth: What do we know so far? A review. Eur. J. Obstet. Gynecol. Reprod. Biol. 2020, 245, 168-173. [CrossRef] [PubMed]

98. Heine, R.P.; Wiesenfeld, H.; Mortimer, L.; Greig, P.C. Amniotic fluid defensins: Potential markers of subclinical intrauterine infection. Clin. Infect. Dis. 1998, 27, 513-518. [CrossRef] [PubMed]

99. Svinarich, D.M.; Gomez, R.; Romero, R. Detection of human defensins in the placenta. Am. J. Reprod. Immunol. 1997, 38, 252-255. [CrossRef]

100. Akinbi, H.T.; Narendran, V.; Pass, A.K.; Markart, P.; Hoath, S.B. Host defense proteins in vernix caseosa and amniotic fluid. Am. J. Obstet. Gynecol. 2004, 191, 2090-2096. [CrossRef]

101. King, A.E.; Kelly, R.W.; Sallenave, J.M.; Bocking, A.D.; Challis, J.R. Innate immune defences in the human uterus during pregnancy. Placenta 2007, 28, 1099-1106. [CrossRef] [PubMed]

102. Ramuta, T.; Šket, T.; Starčič Erjavec, M.; Kreft, M.E. Antimicrobial activity of human fetal membranes: From biological function to clinical use. Front. Bioeng. Biotechnol. 2021, 9, 691522. [CrossRef] [PubMed]

103. Zhao, C.; Wang, I.; Lehrer, R.I. Widespread expression of beta-defensin hbd-1 in human secretory glands and epithelial cells. FEBS Lett. 1996, 396, 319-322. [CrossRef]

104. Feng, Y.; Pan, X.; Huang, N.; Feng, Y.; Wu, Q.; Wang, B. The human beta-defensins expression in female genital tract and pregnancy-related tissues. Sichuan Da Xue Xue Bao Yi Xue Ban 2003, 34, 217-219. [PubMed]

105. Soto, E.; Espinoza, J.; Nien, J.K.; Kusanovic, J.P.; Erez, O.; Richani, K.; Santolaya-Forgas, J.; Romero, R. Human beta-defensin-2: A natural antimicrobial peptide present in amniotic fluid participates in the host response to microbial invasion of the amniotic cavity. J. Matern. Fetal Neonatal. Med. 2007, 20, 15-22. [CrossRef] [PubMed]

106. Varrey, A.; Romero, R.; Panaitescu, B.; Miller, D.; Chaiworapongsa, T.; Patwardhan, M.; Faro, J.; Pacora, P.; Hassan, S.S.; Hsu, C.D.; et al. Human $\beta$-defensin-1: A natural antimicrobial peptide present in amniotic fluid that is increased in spontaneous preterm labor with intra-amniotic infection. Am. J. Reprod. Immunol. 2018, 80, e13031. [CrossRef] [PubMed]

107. Dorschner, R.A.; Lin, K.H.; Murakami, M.; Gallo, R.L. Neonatal skin in mice and humans expresses increased levels of antimicrobial peptides: Innate immunity during development of the adaptive response. Pediatr. Res. 2003, 53, 566-572. [CrossRef] [PubMed] 
108. Yoshio, H.; Tollin, M.; Gudmundsson, G.H.; Lagercrantz, H.; Jornvall, H.; Marchini, G.; Agerberth, B. Antimicrobial polypeptides of human vernix caseosa and amniotic fluid: Implications for newborn innate defense. Pediatr. Res. 2003, 53, 211-216. [CrossRef] [PubMed]

109. Pacora, P.; Maymon, E.; Gervasi, M.T.; Gomez, R.; Edwin, S.S.; Yoon, B.H.; Romero, R. Lactoferrin in intrauterine infection, human parturition, and rupture of fetal membranes. Am. J. Obstet. Gynecol. 2000, 183, 904-910. [CrossRef] [PubMed]

110. Niemelä, A.; Kulomaa, M.; Vija, P.; Tuohimaa, P.; Saarikoski, S. Lactoferrin in human amniotic fluid. Hum. Reprod. 1989, 4, 99-101. [CrossRef] [PubMed]

111. Ma, B.; Forney, L.J.; Ravel, J. Vaginal microbiome: Rethinking health and disease. Annu. Rev. MicroBiol. 2012, 66, 371-389. [CrossRef]

112. Aagaard, K.; Ma, J.; Antony, K.M.; Ganu, R.; Petrosino, J.; Versalovic, J. The placenta harbors a unique microbiome. Sci. Transl. Med. 2014, 6, 237ra265. [CrossRef] [PubMed]

113. Romero, R.; Hassan, S.S.; Gajer, P.; Tarca, A.L.; Fadrosh, D.W.; Nikita, L.; Galuppi, M.; Lamont, R.F.; Chaemsaithong, P.; Miranda, J.; et al. The composition and stability of the vaginal microbiota of normal pregnant women is different from that of non-pregnant women. Microbiome 2014, 2, 4. [CrossRef] [PubMed]

114. Ravel, J.; Gajer, P.; Abdo, Z.; Schneider, G.M.; Koenig, S.S.; McCulle, S.L.; Karlebach, S.; Gorle, R.; Russell, J.; Tacket, C.O.; et al. Vaginal microbiome of reproductive-age women. Proc. Natl. Acad. Sci. USA 2011, 108, 4680-4687. [CrossRef]

115. Ramos Bde, A.; Kanninen, T.T.; Sisti, G.; Witkin, S.S. Microorganisms in the female genital tract during pregnancy: Tolerance versus pathogenesis. Am. J. Reprod. Immunol. 2015, 73, 383-389. [CrossRef]

116. Brown, R.G.; Marchesi, J.R.; Lee, Y.S.; Smith, A.; Lehne, B.; Kindinger, L.M.; Terzidou, V.; Holmes, E.; Nicholson, J.K.; Bennett, P.R.; et al. Vaginal dysbiosis increases risk of preterm fetal membrane rupture, neonatal sepsis and is exacerbated by erythromycin. BMC Med. 2018, 16, 9. [CrossRef]

117. Balu, R.B.; Savitz, D.A.; Ananth, C.V.; Hartmann, K.E.; Miller, W.C.; Thorp, J.M.; Heine, R.P. Bacterial vaginosis, vaginal fluid neutrophil defensins, and preterm birth. Obstet. Gynecol. 2003, 101, 862-868.

118. Mitchell, C.; Gottsch, M.L.; Liu, C.; Fredricks, D.N.; Nelson, D.B. Associations between vaginal bacteria and levels of vaginal defensins in pregnant women. Am. J. Obstet. Gynecol. 2013, 208, 132.e1-132.e7. [CrossRef]

119. Xu, J.; Holzman, C.B.; Arvidson, C.G.; Chung, H.; Goepfert, A.R. Midpregnancy vaginal fluid defensins, bacterial vaginosis, and risk of preterm delivery. Obstet. Gynecol. 2008, 112, 524-531. [CrossRef]

120. Hezelgrave, N.L.; Seed, P.T.; Chin-Smith, E.C.; Ridout, A.E.; Shennan, A.H.; Tribe, R.M. Cervicovaginal natural antimicrobial expression in pregnancy and association with spontaneous preterm birth. Sci. Rep. 2020, 10, 12018. [CrossRef] [PubMed]

121. Burris, H.H.; Riis, V.M.; Schmidt, I.; Gerson, K.D.; Brown, A.; Elovitz, M.A. Maternal stress, low cervicovaginal $\beta$-defensin, and spontaneous preterm birth. Am. J. Obstet. Gynecol. MFM 2020, 2, 100092. [CrossRef] [PubMed]

122. Tambor, V.; Kacerovsky, M.; Andrys, C.; Musilova, I.; Hornychova, H.; Pliskova, L.; Link, M.; Stulik, J.; Lenco, J. Amniotic fluid cathelicidin in pprom pregnancies: From proteomic discovery to assessing its potential in inflammatory complications diagnosis PLoS ONE 2012, 7, e41164. [CrossRef] [PubMed]

123. Buhimschi, I.A.; Jabr, M.; Buhimschi, C.S.; Petkova, A.P.; Weiner, C.P.; Saed, G.M. The novel antimicrobial peptide beta3-defensin is produced by the amnion: A possible role of the fetal membranes in innate immunity of the amniotic cavity. Am. J. Obstet. Gynecol. 2004, 191, 1678-1687. [CrossRef] [PubMed]

124. Stock, S.J.; Kelly, R.W.; Riley, S.C.; Calder, A.A. Natural antimicrobial production by the amnion. Am. J. Obstet. Gynecol. 2007, 196, 255.e1-255.e6. [CrossRef]

125. Tehrani, F.A.; Modaresifar, K.; Azizian, S.; Niknejad, H. Induction of antimicrobial peptides secretion by il-1 $\beta$ enhances human amniotic membrane for regenerative medicine. Sci. Rep. 2017, 7, 17022. [CrossRef] [PubMed]

126. Erez, O.; Romero, R.; Tarca, A.L.; Chaiworapongsa, T.; Kim, Y.M.; Than, N.G.; Vaisbuch, E.; Draghici, S.; Tromp, G. Differential expression pattern of genes encoding for anti-microbial peptides in the fetal membranes of patients with spontaneous preterm labor and intact membranes and those with preterm prelabor rupture of the membranes. J. Matern. Fetal Neonatal Med. 2009, 22, 1103-1115. [CrossRef]

127. King, A.E.; Paltoo, A.; Kelly, R.W.; Sallenave, J.M.; Bocking, A.D.; Challis, J.R. Expression of natural antimicrobials by human placenta and fetal membranes. Placenta 2007, 28, 161-169. [CrossRef] [PubMed]

128. Strauss, J.F., 3rd; Romero, R.; Gomez-Lopez, N.; Haymond-Thornburg, H.; Modi, B.P.; Teves, M.E.; Pearson, L.N.; York, T.P.; Schenkein, H.A. Spontaneous preterm birth: Advances toward the discovery of genetic predisposition. Am. J. Obstet. Gynecol. 2018, 218, 294-314.e292. [CrossRef]

129. Modi, B.P.; Teves, M.E.; Pearson, L.N.; Parikh, H.I.; Haymond-Thornburg, H.; Tucker, J.L.; Chaemsaithong, P.; Gomez-Lopez, N.; York, T.P.; Romero, R.; et al. Mutations in fetal genes involved in innate immunity and host defense against microbes increase risk of preterm premature rupture of membranes (pprom). Mol. Genet. Genom. Med. 2017, 5, 720-729. [CrossRef]

130. Son, G.H.; Choi, S.Y.; Ju, Y.J.; Lee, K.Y.; Lee, J.J.; Song, J.E.; Kim, Y.; Park, S.T. Whole blood rna sequencing reveals a differential transcriptomic profile associated with cervical insufficiency: A pilot study. Reprod. Biol. Endocrinol. 2021, 19, 32. [CrossRef] 